\title{
The Role of Hedgehog Signalling in the Formation of the Ventricular Septum
}

\author{
Antonia Wiegering, Ulrich Rüther and Christoph Gerhardt * \\ Institute for Animal Developmental and Molecular Biology, Heinrich-Heine University Düsseldorf, \\ 40225 Düsseldorf, Germany; antonia.wiegering@hhu.de (A.W.); ruether@hhu.de (U.R.) \\ * Correspondence: christoph.gerhardt@hhu.de; Tel.: +49-(0)211-81-12236
}

Received: 30 November 2017; Accepted: 9 December 2017; Published: 12 December 2017

\begin{abstract}
An incomplete septation of the ventricles in the vertebrate heart that disturbes the strict separation between the contents of the two ventricles is termed a ventricular septal defect (VSD). Together with bicuspid aortic valves, it is the most frequent congenital heart disease in humans. Until now, life-threatening VSDs are usually treated surgically. To avoid surgery and to develop an alternative therapy (e.g., a small molecule therapy), it is necessary to understand the molecular mechanisms underlying ventricular septum (VS) development. Consequently, various studies focus on the investigation of signalling pathways, which play essential roles in the formation of the VS. In the past decade, several reports found evidence for an involvement of Hedgehog $(\mathrm{HH})$ signalling in VS development. In this review article, we will summarise the current knowledge about the association between $\mathrm{HH}$ signalling and VS formation and discuss the use of such knowledge to design treatment strategies against the development of VSDs.
\end{abstract}

Keywords: ventricular septal defect; VSD; Smoothened; SMO; SAG; purmorphamine; oxysterols; GSA-10; cilia; Down syndrome

\section{Introduction}

100 years ago, David Waterston reported that the ventricular septum (VS) grows out from the anterior bulboventricular groove [1]. In 1940, John Ernest Frazer identified the atrioventricular endocardial cushion cells as the original source of VS formation [2], causing a controversial debate about the place of origin from which the ventricular septum is formed. In the 1970s, investigations on congenital heart diseases revealed that the ventricular septum consists of different structures that are built up from different starting points [3-6]. The formation of the muscular part of the ventricular septum starts concomitantly with the ballooning of the linear heart tube [7]. During this ballooning, the heart chambers are specified and the bulboventricular groove develops [8] (Figure 1A-C). From the bulboventricular groove, the muscular ventricular septum arises (Figure 1C-E), while the membranous part of the ventricular septum is formed by the atrioventricular endocardial cushion cells [9] (Figure 1E,F). The development of the muscular ventricular septum is based on the proliferation of cells that are localized in the ventricular walls and takes place concomitantly with the growth of the both ventricles [10,11] (Figure 1C-E). Moreover, many of the trabeculae (intraventricular collections of linearly ordered myocytes) fuse with the growing muscular ventricular septum and accelerate its outgrowth (Figure 1D,E) [12,13]. Since the trabeculae are derived from the myocardial cells of the ventricular walls [14-16], the proliferation of the ventricular wall cells is of outstanding importance for the formation of the muscular ventricular septum $[10,17,18]$. Finally, the muscular VS comprises a mixture of cardiomyocytes derived from the left and the right ventricle [11]. The muscular VS, after its formation, interacts with the atrioventricular endocardial cushion cells in a yet unknown manner, thereby initiating the development of the membranous VS $[9,19,20]$. 
The membranous VS grows from the atrioventricular endocardial cushion cells towards the muscular VS until they finally fuse together $[19,21,22]$ (Figure 1E-G).
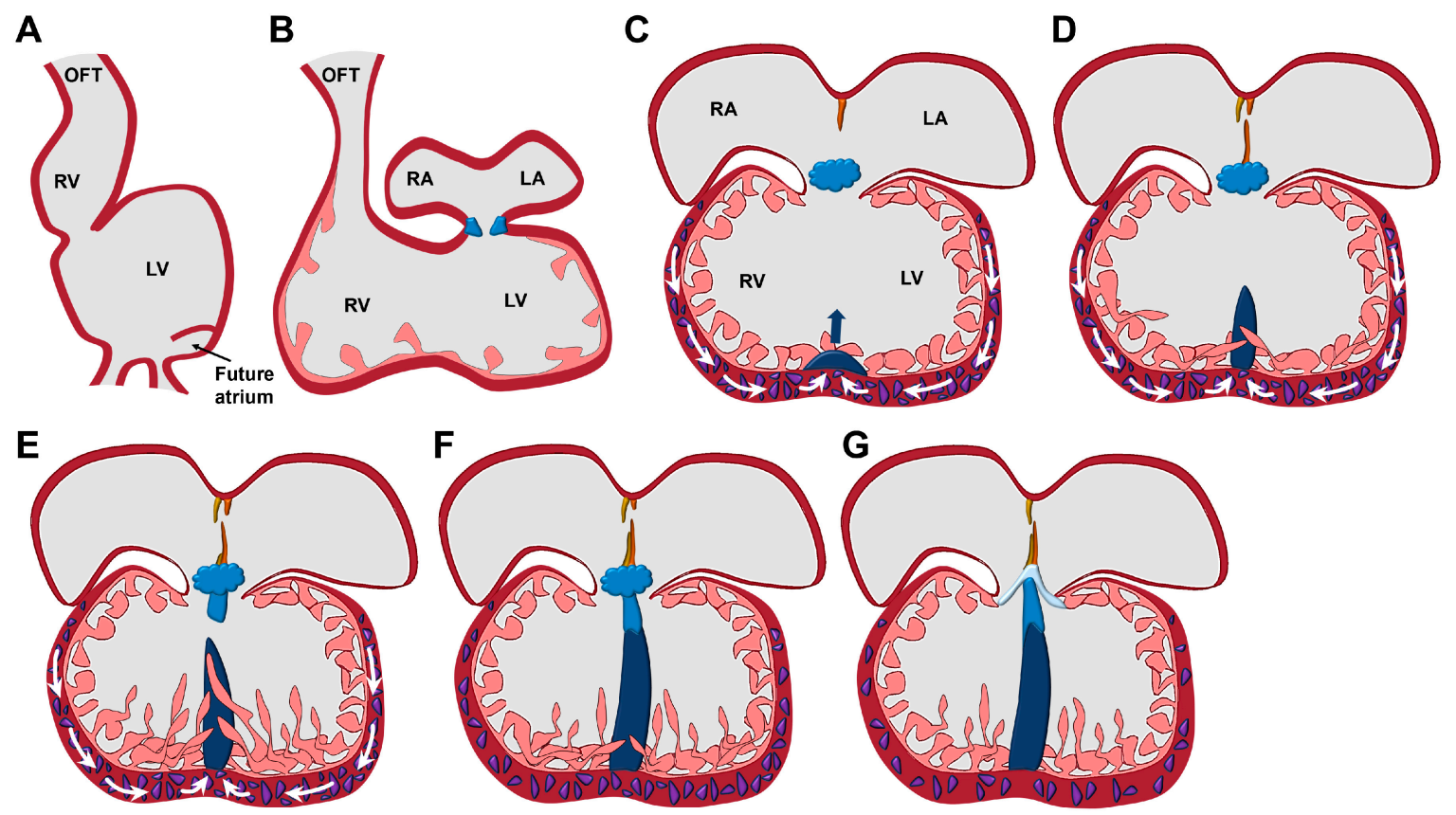

Figure 1. Development of the ventricular septum. (A) The linear heart tube balloons to give rise to precursor structures of the heart chambers. (B) The heart takes its four-chambered shape by a process termed heart looping. (C) Proliferating cells (in purple) of the ventricular walls lead to the outgrowth of the muscular ventricular septum (in dark blue). (D) In addition, trabeculae that are derived from the ventricular walls start to participate in the formation of the ventricular septum. (E) After a molecular interaction between the muscular ventricular septum and the endocardial cushion cells (in bright blue), the membranous ventricular septum develops from the endocardial cushion cells and grows towards the muscular ventricular septum. (F) Finally, the muscular and membranous ventricular septa fuse. (G) The atrioventricular endocardial cushion cells give rise to the atrioventricular valves. LA, left atrium; LV, left ventricle; OFT, outflow tract; RA, right atrium; RV, right ventricle.

An incomplete septation of the ventricles is known as a ventricular septal defect (VSD) and allows for the communication of the left and the right ventricle, which, in turn, results in the mixture of oxygenated and de-oxygenated blood and an increase of the blood flow towards the lung and the left ventricle [23]. The consequence is the emergence of pulmonary edema and dilatation, as well as hypertrophy of the left ventricle [24,25]. Furthermore, the blood flow towards other organs in the body is impaired, and hence their supply of oxygen and nutrients is not ensured. The severity of the defect is dependent on the size of the VSD. The first clinical description of a VSD was provided in 1879 [26]. Together with bicuspid aortic valves, the VSD is the most common congenital heart disease in humans today [27-29]. In most cases, children do not die due to VSDs, but they often suffer from defective heart function as adults $[23,30]$. To prevent these severe consequences, VSDs are currently treated with surgery. Although surgical repair is the most frequently performed procedure in pediatric cardiac surgery, and although this treatment is successfully applied in most cases [31,32], surgical closure of VSDs entails several risks, like chronotropic incompetence, operative mortality, or late death [32,33]. To avoid surgery and to develop alternative therapies to treat VSDs, it is necessary to know the molecular mechanisms underlying ventricular septal development. Since these mechanisms are largely unknown [11,20], a recent report attracted widespread attention. Li et al. reported that a plethora of congenital heart defects in mice are caused by mutations in genes encoding ciliary proteins [34]. Ciliary proteins are essential for the function of cilia, little hair-like, 
cellular protrusions that can be subdivided into two groups. Simplified, one differentiates between motile cilia and immotile cilia [35]. Immotile cilia are also known as primary cilia. They receive signals from their environment, mediate them, and transduce these signals into the cell's interior. Due to this signal transduction, certain gene expressions are regulated within the cell nucleus, and, in turn, cellular processes like proliferation, apoptosis, and differentiation are initiated [36,37]. A signalling pathway that depends highly on the mediation by primary cilia and plays an important role in the development of numerous vertebrate organs is the Hedgehog $(\mathrm{HH})$ signalling pathway [38-44].

In vertebrates, $\mathrm{HH}$ signalling starts with the binding of the ligand $\mathrm{HH}$ [three different vertebrate HH proteins exist-Sonic hedgehog (SHH), Indian hedgehog (IHH), and Desert hedgehog (DHH)] to its receptor Patched (PTC1), which is located in the membrane of primary cilia (Figure 2). One factor that promotes this binding event is Low-density lipoprotein receptor related protein 2 (LRP2) [45]. After the binding event, the HH/PTC1 complex exits the cilium and Smoothened (SMO) is allowed to enter the ciliary membrane $[46,47]$. Upon arriving in the ciliary membrane, SMO dissociates the full-length Glioblastoma 2 (GLI2) and Glioblastoma 3 (GLI3) proteins from Suppressor of Fused (SUFU) via a yet unknown mechanism and transforms them into transcriptional activators (GLI2-A and GLI3-A) [48,49]. This transformation is enabled by the action of the protein Broad-Minded (BROMI; also referred to as TBC1D32) and the ciliary proteins Ellis Van Creveld 1 (EVC1) and Ellis Van Creveld 2 (EVC2) [50-56]. Subsequent to their activation, GLI2-A and GLI3-A translocate into the nucleus and induce HH target gene expression (e.g., the expression of Gli1 or Ptc1). The transport of PTC1, SMO, and GLI2 within primary cilia was shown to be dependent on the Intraflagellar transport proteins 25 and 27 (IFT25 and IFT27) [57-59]. Loss of either IFT25 or IFT27 leads to reduced HH target gene expression $[57,58]$. In the absence of $\mathrm{HH}, \mathrm{PTC} 1$ stays within the ciliary membrane and SMO remains outside the cilium. As a consequence, the cilia-regulated proteasome proteolytically processes the full-length GLI2 and GLI3 proteins into transcriptional repressors (GLI2-R and GLI3-R) [60-62]. This proteolytic processing event starts with the phosphorylation of GLI2 and GLI3 by protein kinase A (PKA), Casein kinase 1 (CK1), and Glycogen synthase kinase 3- $\beta$ (GSK3- $\beta$ ) [63-65]. Furthermore, the proteins Kinesin family member 7 (KIF7) and Fuzzy (FUZ) seem to be involved in the processing of GLI2 and GLI3, and also in the conversion of their full-length forms into transcriptional activators by yet unknown mechanisms [66-70].

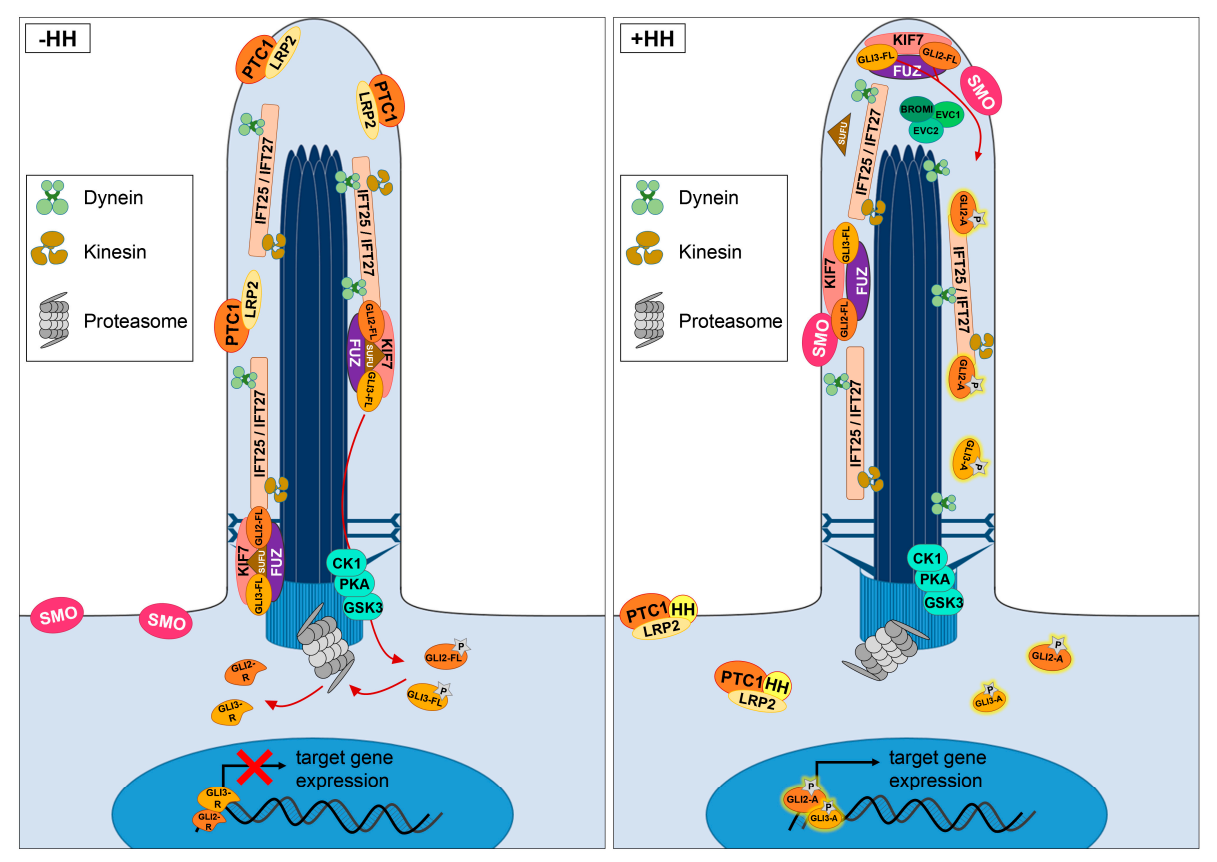

Figure 2. Hedgehog signalling at primary cilia. 
In vertebrates, $\mathrm{HH}$ signalling is mediated by primary cilia. The transport of proteins through the cilium is performed by the motor proteins Kinesin and Dynein, as well as by IFT proteins, in the case of HH signalling components especially by IFT25 and IFT27. In the absence of the HH ligand, PTC1 prevents the ciliary entry of SMO. GLI2-FL and GLI3-FL are bound to SUFU and get phosphorylated by PKA, CK1, and GSK3- $\beta$. Subsequently, GLI2-FL and GLI3-FL undergo proteolytic processing, which is realised by the cilia-regulated proteasome. Moreover, KIF7 and FUZ were reported to be involved in the proteolytic processing of these proteins. The products of this processing event, GLI2-R and GLI3-R, translocate into the nucleus to inhibit HH target gene expression. In the presence of $\mathrm{HH}$, the ligand binds to PTC1. This binding is supported by the co-receptor LRP2. After this binding event, the PTC1/LRP2/HH complex exits the cilium allowing SMO to enter the cilium. Within the cilium, SMO induces the dissociation of the GLI2-FL and GLI3-FL proteins from SUFU. With the support of BROMI, EVC1, and EVC2, SMO modifies GLI2-FL and GLI3-FL into the transcriptional activators GLI2-A and GLI3-A (most likely by phosphorylation). After this modification, GLI2-A and GLI3-A activate HH target gene expression.

\section{HH Signalling Plays an Essential Role in the Development of the VS}

To evaluate the importance of $\mathrm{HH}$ signalling in the formation of the human VS, cardiac investigations of mice in which $\mathrm{HH}$ signalling components are truncated or inactivated give expressive statements (for an overview see Table 1). Shh ${ }^{-/-}$mice are not viable and $S h h^{-/-}$ mouse embryos display several heart defects, including, inter alia, atrioventricular septal defects (AVSDs) [71]. In contrast to Shh mutant mice, until now, congenital heart defects were not described in Ihh or Dhh mutant mice. Mutation of Lrp2 results in the development of persistent truncus arteriosus, aortic arch defects, and VSDs in murine embryos [34]. Sufu mutant mouse embryos display ventricular septal defects and other cardiac defects, while Bromi mutant mouse embryos exhibit, amongst other heart malformations, AVSDs [34]. Moreover, Ift $25^{-/-}$and Ift2 $7^{-/-}$mouse embryos display VSDs, AVSDs, and other heart defects $[57,58]$. Consequently, mutations in many genes whose products positively control $\mathrm{HH}$ signalling result in the development of VSDs in mice, indicating that $\mathrm{HH}$ signalling is important for proper VS development. However, mutations in several genes that encode negative regulators of $\mathrm{HH}$ signalling also lead to the occurrence of VSDs. In this context, the loss of GSK3- $\beta$ in mice results in the development of VSDs [72]. Furthermore, Kif7 and Fuz mutant mouse embryos show AVSDs [34,73]. These three proteins, GSK3- $\beta$, KIF7, and FUZ, are necessary for proteolytic processing of GLI2 and GLI3, indicating that the inhibition of $\mathrm{HH}$ target gene expression might be an important factor for proper VS development. If this hypothesis is true, lack of either GLI2-R or GLI3-R should lead to the onset of VSDs. When considering that GLI3-R is the main transcriptional repressor in the $\mathrm{HH}$ pathway, the VS formation in $\mathrm{Gli3}^{-/-}$mouse embryos is the best parameter to test this hypothesis. Remarkably, GLI3 deficiency does not result in the development of VSDs [74]. This finding is a very good hint for the possibility that the downregulation of $\mathrm{HH}$ signalling has a negative rather than a positive effect on the outgrowth of the VS in mice. Assuming that the GLI3-R is not a decisive factor in VS formation, it is conceivable that the occurrence of VSDs in Gsk3- $\beta^{-/-}$, Kif $7^{-/-}$ and $\mathrm{Fuz}^{-/-}$mouse embryos results from the influence of these genes and their products in other signalling pathways than the HH pathway. It was previously reported that GSK3- $\beta$ participates in the regulation of several signalling pathways, like canonical WNT signalling, NOTCH signalling and TGF- $\beta$ signalling which participate in the formation of the VS [75-83]. KIF7 and FUZ have an effect on other signalling pathways via their involvement in ensuring proper cilia function $[66,69,70,84-88]$. Moreover, KIF7 and FUZ do not only take part in the generation of the GLI3-R, but also in the production of the GLI3-A [66-70], making it possible that VSDs in Kif ${ }^{-/-}$and $\mathrm{Fuz}^{-/-}$mouse embryos are caused by a reduced amount of the GLI3-A. Importantly, the significant role of HH signalling in the development of the VS is conserved in humans. Patients carrying mutations in EVC1 or EVC2 suffer from VSDs and other cardiac malformations $[89,90]$. Furthermore, an association between a reduced expression of the HH target gene GLI1 and the occurrence of VSDs was reported in Down syndrome 
patients [91]. In summary, these data obtained from studies in patients and mouse models indicate that $\mathrm{HH}$ signalling is essential for proper VS development and that any disruption of this pathway can lead to the development of VSDs.

Table 1. Heart phenotypes of humans and mice mutant for genes encoding Hedgehog signalling components.

\begin{tabular}{|c|c|c|}
\hline Gene Symbol & Cardiac Phenotype & Literature \\
\hline Shh & $\begin{array}{ll}\text { - } & \text { AVSDs } \\
\text { - } & \text { Arch artery and outflow tract patterning defects } \\
\text { - } & \text { Abnormal development of migratory neural crest cells }\end{array}$ & [71] \\
\hline Lrp2 & $\begin{array}{ll}\text { - } & \text { VSDs } \\
\text { - } & \text { Aortic arch defects } \\
\text { - } & \text { Persistent truncus arteriosus }\end{array}$ & [34] \\
\hline Sufu & $\begin{array}{ll}\text { - } & \text { VSDs } \\
\text { - } & \text { Coronary artery abnormalities } \\
\text { - } & \text { Double outlet right ventricle/overriding aorta }\end{array}$ & {$[34]$} \\
\hline Bromi (Tbc1d32) & $\begin{array}{ll}\text { - } & \text { AVSDs } \\
\text { - } & \text { Congenital heart defects } \\
\end{array}$ & {$[34]$} \\
\hline Ift 25 & $\begin{array}{ll}\text { - } & \text { AVSDs } \\
\text { - } & \text { VSDs } \\
\text { - } & \text { Double outlet right ventricle/overriding aorta } \\
\text { - } & \text { Common atrium } \\
\text { - } & \text { Outflow tract malalignment defects }\end{array}$ & {$[57,58]$} \\
\hline Ift 27 & $\begin{array}{ll}\text { - } & \text { AVSDs } \\
\text { - } & \text { VSDs } \\
\text { - } & \text { Double outlet right ventricle } \\
\text { - } & \text { Common atrium } \\
\text { - } & \text { Hypoplasia of the pulmonary trunc } \\
\text { - } & \text { Pulmonary artery defects } \\
\text { - } & \text { Aortic arch anomalities }\end{array}$ & {$[57,58]$} \\
\hline EVC1 & $\begin{array}{ll}\text { - } & \text { AVSDs } \\
\text { - } & \text { Common atrium } \\
\text { - } & \text { Persistent superior left vena cava } \\
\end{array}$ & {$[86,87]$} \\
\hline$E V C 2$ & $\begin{array}{ll}\text { - } & \text { AVSDs } \\
\text { - } & \text { Common atrium } \\
\text { - } & \text { Persistent superior left vena cava }\end{array}$ & {$[86,87]$} \\
\hline Kif7 & $\begin{array}{ll}\text { - } & \text { AVSDs } \\
\text { - } & \text { Double outlet right ventricle/overriding aorta } \\
\text { - } & \text { Pulmonary artery hypoplasia } \\
\text { - } & \text { Interrupted aortic arch } \\
\end{array}$ & {$[34,73]$} \\
\hline Fuz & $\begin{array}{ll}\text { - } & \text { AVSDs } \\
\text { - } & \text { Dual inferior vena cava } \\
\text { - } & \text { Multiple major aortopulmonary collateral arteries } \\
\text { - } & \text { pulmonary valve atresia } \\
\text { - } & \text { right aortic arch }\end{array}$ & {$[34,73]$} \\
\hline Gsk3- $\beta$ & $\begin{array}{ll}\text { - } & \text { VSDs } \\
\text { - } & \text { Atrioventricular canal defect } \\
\text { - } & \text { Double outlet right ventricle }\end{array}$ & [72] \\
\hline
\end{tabular}

$\mathrm{HH}$ signalling regulates VS formation at different time points and from various locations. In mice, the first influence of $\mathrm{HH}$ signalling on the development of the VS seems to be at around embryonic day (E) 7.0 to E7.5. At this time, $\mathrm{HH}$ signalling from the pharyngeal endoderm ensures the proper genesis 
of the second heart field [71,92-97]. It governs the proliferation of second heart field cells, which are cardiac progenitor cells in the pharyngeal mesoderm, via the Wnt/ $\beta$-catenin signalling pathway, the T-box transcription factor 5 (TBX5), and Forkhead box transcription factors 1a and 2 (FOXF1a and FOXF2) $[78,98-100]$. These cells attach to the growing arterial and venous poles of the linear heart tube in order to drive its elongation $[94,101]$. Subsequent to this elongation event, the linear heart tube is formed into a four-chambered heart by two processes, which are termed heart looping and septation. The heart looping process depends on the establishment of the left-right asymmetry that is realised at the node (a unique cohort of cells at the anterior tip of the primitive streak during gastrulation) in mammals [102]. In mice, the establishment of left-right asymmetry takes place at E7.75 to E8.0 [103]. At this time, $\mathrm{HH}$ is essential for the proper establishment of left-right asymmetry at the node. So called nodal vesicular parcels (NVPs), which contain $\mathrm{HH}$, are transported to the left side of the node via the nodal flow that is created by the movement of motile cilia [104]. Upon arrival at the left side of the node (lateral plate mesoderm), $\mathrm{HH}$ initiates a signalling cascade that determines left identities in mice [105]. Remarkably, $\mathrm{HH}$ signalling controls the establishment of left-right asymmetry not only in mice, but also in other vertebrates [106-109]. If the establishment of left-right asymmetry fails, the organs within the vertebrate body are distributed randomly (heterotaxy) [110]. As one consequence of this defect, VSDs can occur since impaired left-right asymmetry affects the looping of the linear heart tube. In turn, this disturbed looping causes a disrupted arrangement of atrioventricular endocardial cushion cells, which are essential for proper membranous VS formation [111]. Furthermore, second heart field defects often result in VSDs $[78,93,98,112-114]$. It was previously reported that second heart field defects can result in an impaired development of the outflow tract [115-117]. Since it is known that the development of the muscular VS can be affected by outflow tract defects [118], it is conceivable that the occurrence of these outflow tract defects finally provoke the development of VSDs under second heart field defect conditions. Thus, HH signalling controls the development of the VS from two different regions outside the heart.

In addition to extracardiac $\mathrm{HH}$ signalling, intracardiac $\mathrm{HH}$ signalling participates in the formation of the VS. Cilia-mediated HH signalling governs the proliferation of myocardial cells in distinct regions of the ventricular walls [119]. The decrease of $\mathrm{HH}$ signalling due to a dysfunction of cilia in these regions results in an impaired myocardial proliferation, and finally to the occurrence of thinner ventricular walls and the development of VSDs in mice. In this context, $\mathrm{HH}$ signalling governs the outgrowth of the muscular part of the VS. However, the membranous part of the VS is indirectly affected since an impaired formation of the muscular VS impedes the development of the membranous septum [119]. Interestingly, HH signalling ensures the proper ciliary localization of PDGFR $\alpha$ in these cardiac cilia [119]. In combination with the fact that Pdgfr $\alpha$ mutant mouse embryos exhibit VSDs $[120,121]$, it is likely that intracardiac HH signalling regulates VS formation via controlling PDGFR $\alpha$ signalling [119]. To sum up, the formation of the VS is regulated via HH signalling in the pharyngeal endoderm, at the left side of the node and in the ventricular walls. Any impairment of the $\mathrm{HH}$ signalling transduction cascade in these different areas and the associated different processes can lead to the occurrence of VSDs. Consequently, $\mathrm{HH}$ signalling plays an important role in proper VS genesis.

\section{Is It Possible to Prevent the Development of VSDs by Targeting HH Signalling in Pregnancy?}

Once a large VSD has been diagnosed in a newborn, it is difficult to imagine that a pharmacological treatment is able to close the defect. Consequently, maternal exposure to small molecules during pregnancy could be an option to prevent the development of VSDs. A good example for such a therapy is the preconceptional intake of folic acid to avoid the development of neural tube defects [122]. When considering that decreased HH signalling can result in the occurrence of VSDs, the restoration of disturbed HH might prevent the development of VSDs. In the case of reduced HH signalling, SMO agonists are promising candidates for therapeutic approaches [123]. Known SMO agonists are the benzothiophene SAG [124], the trisubstituted purine purmorphamine [125], oxysterols [126] and 
the quinolinone GSA-10 [127]. They control SMO activity via a direct interaction. However, the use of these small molecules for therapeutic purposes has to be extensively tested since hyperactivated $\mathrm{HH}$ signalling has teratogenic potential entailing several risks, like, for example, the formation of tumors in certain organs [128-137]. Furthermore, it was reported that a single injection of SAG in pregnant mice at E9.25 leads to pre-axial polydactyly in their embryos [138]. In this context, it cannot be excluded that SMO agonists have an effect on other signalling pathways that are involved in VS formation, like the canonical WNT pathway, the NOTCH pathway, or the TGF- $\beta$ pathway. The general point of view is that $\mathrm{HH}$ agonists might influence other pathways indirectly via stimulating $\mathrm{HH}$ signalling. Since there are also cross-reactions of canonical WNT signalling, NOTCH signalling and TGF- $\beta$ signalling with the repressor arm of HH signalling (e.g., GSK3- $\beta$ ) $[139,140]$, it is even possible that HH agonists indirectly activate GLI2-R and GLI3-R. A recent report showed that SAG is not able to alter canonical Wnt signalling in murine F9 cells (teratocarcinoma stem cells [141]) [142], but, to our knowledge, such studies were never performed in cardiac cells. Accordingly, it will be a difficult task in future to stimulate $\mathrm{HH}$ signalling to an adequate degree at the convenient time.

Patients suffering from Down syndrome often develop VSDs [143-146]. As mentioned before, a study showed a relation between a decreased expression of the HH target gene GLI1 and the appearance of VSDs in Down syndrome patients [91], indicating that reduced HH signalling provokes VSDs in these patients. This hypothesis is supported by the fact that there are significant similarities between the heart phenotypes that are observed in $\mathrm{HH}$ signalling mutant mice and those seen in Down syndrome mouse models [147]. In regard to the development of VSDs, it is remarkable that a hypoplastic dorsal mesenchymal protrusion (a tissue derived from the second heart field) was found in Down syndrome patients and mouse models [148-150]. Under the assumption that reduced $\mathrm{HH}$ signalling causes several defects in Down syndrome patients, a mouse model of Down syndrome was treated with SAG. Injection of SAG into newborn pups corrected cerebellar dysmorphology [151] and hippocampal function [152], but cerebellar function is not restored completely [153]. Until now, studies that describe the effect of SAG treatment on the frequency of VSDs in Down syndrome mice were not reported. Since VS formation is already finished at birth, it would be necessary to treat pregnant Down syndrome mice with SAG and to analyse the VS phenotype of their progeny. Potentially, studies in Down syndrome mouse models might provide the opportunity to test $\mathrm{HH}$ signalling agonists as promising candidates to realize the development of a pharmacological therapy to prevent the occurrence of VSDs.

Acknowledgments: This work was supported by the Deutsche Forschungsgemeinschaft (Sonderforschungsbereiche 590 and 612) to U. R.

Conflicts of Interest: The authors declare that they have no competing interests.

\section{References}

1. Waterston, D. The development of the heart in man. Trans. R. Soc. Edinb. 1918, 52, 257-302. [CrossRef]

2. Frazer, J. A Manual of Embryology. In Development of the Heart, and Vessels of the Anterior Part of the Embryo, 2nd ed.; Bailliere, Tindall and Cox: London, UK, 1940; pp. 322-352.

3. Goor, D.; Edwards, J.; Lillehei, C. The development of the interventricular septum of the human heart; Correlative morphogenetic study. Chest 1970, 58, 453-467. [CrossRef] [PubMed]

4. Goor, D.; Lillehei, C.; Rees, R.; Edwards, J. Isolated ventricular septal defect. Development basis for various types and presentation of classification. Chest 1970, 58, 468-482. [CrossRef] [PubMed]

5. Wenink, A. The conducting tissues in primitive ventricle with outlet chamber. Two different possibilities. J. Thorac. Cardiovasc. Surg. 1978, 75, 747-753. [PubMed]

6. Wenink, A.; Oppenheimer-Dekker, A.; Moulaert, A. Muscular ventricular septal defects: A reappraisal of the anatomy. Am. J. Cardiol. 1979, 43, 259-264. [CrossRef]

7. Anderson, R.; Spicer, D.; Brown, N.; Mohun, T. The development of septation in the four-chambered heart. Anat. Rec. 2014, 297, 1414-1429. [CrossRef] [PubMed] 
8. Moorman, A.; Christoffels, V. Cardiac chamber formation: Development, genes, and evolution. Physiol. Rev. 2003, 83, 1223-1267. [CrossRef] [PubMed]

9. Eisenberg, L.; Markwald, R. Molecular regulation of atrioventricular valvuloseptal morphogenesis. Circ. Res. 1995, 77, 1-6. [CrossRef] [PubMed]

10. Steding, G.; Seidl, W. Contribution to the development of the heart. Part 1: Normal development. Thorac. Cardiovasc. Surg. 1980, 28, 386-409. [CrossRef] [PubMed]

11. Franco, D.; Meilhac, S.; Christoffels, V.; Kispert, A.; Buckingham, M.; Kelly, R. Left and right ventricular contributions to the formation of the interventricular septum in the mouse heart. Dev. Biol. 2006, 294, 366-375. [CrossRef] [PubMed]

12. Ben-Shachar, G.; Arcilla, R.; Lucas, R.; Manasek, F. Ventricular trabeculations in the chick embryo heart and their contribution to ventricular and muscular septal development. Circ. Res. 1985, 57, 759-766. [CrossRef] [PubMed]

13. Contreras-Ramos, A.; Sánchez-Gómez, C.; García-Romero, H.; Cimarosti, L. Normal development of the muscular region of the interventricular septum-I. The significance of the ventricular trabeculations. Anat. Histol. Embryol. 2008, 37, 344-351. [CrossRef] [PubMed]

14. Hochstetter, F. Entwicklung des Venensystems. In Handbuch der Vergleichenden und Experimentellen Entwicklungslehre der Wirbeltiere; Gustav Fischer: Jena, Germany, 1906; Volume 3, pp. 141-145.

15. Patten, B. Development of the chick during the third and fourth days of incubation. In Early Embryology of the Chick, 4th ed.; McGraw-Hill: New York, NY, USA, 1951; pp. 156-213.

16. Goor, D.; Lillehei, C. The embryology of the heart. In Congenital Malformations of the Heart; Grune \& Stratton: Orlando, FL, USA, 1975; pp. 38-88.

17. Rychter, Z.; Rychterová, V.; Lemez, L. Formation of the heart loop and proliferation structure of its wall as a base for ventricular septation. Herz 1979, 4, 86-90. [PubMed]

18. Van Mierop, L.; Kutsche, L. Development of the ventricular septum of the heart. Heart Vessels 1985, 1, 114-119. [CrossRef] [PubMed]

19. Meredith, M.; Hutchins, G.; Moore, G. Role of the left interventricular sulcus in formation of interventricular septum and crista supraventricularis in normal human cardiogenesis. Anat. Rec. 1979, 194, 417-428. [CrossRef] [PubMed]

20. Sakata, Y.; Kamei, C.; Nakagami, H.; Bronson, R.; Liao, J.; Chin, M. Ventricular septal defect and cardiomyopathy in mice lacking the transcription factor CHF1/Hey2. Proc. Natl. Acad. Sci. USA 2002, 99, 16197-16202. [CrossRef] [PubMed]

21. Lamers, W.; Moorman, A. Cardiac septation: A late contribution of the embryonic primary myocardium to heart morphogenesis. Circ. Res. 2002, 91, 93-103. [CrossRef] [PubMed]

22. Komatsu, K.; Wakatsuki, S.; Yamada, S.; Yamamura, K.; Miyazaki, J.; Sehara-Fujisawa, A. Meltrin $\beta$ expressed in cardiac neural crest cells is required for ventricular septum formation of the heart. Dev. Biol. 2007, 303, 82-92. [CrossRef] [PubMed]

23. Brickner, M.; Hillis, L.; Lange, R. Congenital heart disease in adults. First of two parts. N. Engl. J. Med. 2000, 342, 256-263. [CrossRef] [PubMed]

24. Ferreira, A.; Shenoy, V.; Yamazato, Y.; Sriramula, S.; Francis, J.; Yuan, L.; Castellano, R.; Ostrov, D.; Oh, S.; Katovich, M.; et al. Evidence for angiotensin-converting enzyme 2 as a therapeutic target for the prevention of pulmonary hypertension. Am. J. Respir. Crit. Care Med. 2009, 179, 1048-1054. [CrossRef] [PubMed]

25. Selicorni, A.; Colli, A.; Passarini, A.; Milani, D.; Cereda, A.; Cerutti, M.; Maitz, S.; Alloni, V.; Salvini, L.; Galli, M.; et al. Analysis of congenital heart defects in 87 consecutive patients with Brachmann-de Lange syndrome. Am. J. Med. Genet. A 2009, 149A, 1268-1272. [CrossRef] [PubMed]

26. Roger, $\mathrm{H}$. Clinical researches on the congenital communication of the two sides of the heart by failure of occlusion of the interventricular septum. Bull. Acad. Med. 1879, 8, 1074-1094.

27. Hoffman, J.; Kaplan, S. The incidence of congenital heart disease. J. Am. Coll. Cardiol. 2002, 39, 1890-1900. [CrossRef]

28. Williams, D. Bicuspid aortic valve. J. Insur. Med. 2006, 38, 72-74. [PubMed]

29. Benjamin, E.; Blaha, M.; Chiuve, S.; Cushman, M.; Das, S.; Deo, R.; de Ferranti, S.; Floyd, J.; Fornage, M.; Gillespie, C.; et al. Heart Disease and Stroke Statistics-2017 Update: A Report From the American Heart Association. Circulation 2017, 135, e146-e603. [CrossRef] [PubMed]

30. Srivastava, D. Heart disease: An ongoing genetic battle? Nature 2004, 429, 819-822. [CrossRef] [PubMed] 
31. Schipper, M.; Slieker, M.; Schoof, P.; Breur, J. Surgical Repair of Ventricular Septal Defect; Contemporary Results and Risk Factors for a Complicated Course. Pediatr. Cardiol. 2017, 38, 264-270. [CrossRef] [PubMed]

32. Scully, B.; Morales, D.; Zafar, F.; McKenzie, E.; Fraser, C.J.; Heinle, J. Current expectations for surgical repair of isolated ventricular septal defects. Ann. Thorac. Surg. 2010, 89, 544-549. [CrossRef] [PubMed]

33. Heiberg, J.; Nyboe, C.; Hjortdal, V. Permanent chronotropic impairment after closure of atrial or ventricular septal defect. Scand. Cardiovasc. J. 2017, 51, 271-276. [CrossRef] [PubMed]

34. Li, Y.; Klena, N.; Gabriel, G.; Liu, X.; Kim, A.; Lemke, K.; Chen, Y.; Chatterjee, B.; Devine, W.; Damerla, R.; et al. Global genetic analysis in mice unveils central role for cilia in congenital heart disease. Nature 2015, 521, 520-524. [CrossRef] [PubMed]

35. Satir, P.; Pedersen, L.; Christensen, S. The primary cilium at a glance. J. Cell Sci. 2010, 123, 499-503. [CrossRef] [PubMed]

36. Bisgrove, B.; Yost, H. The roles of cilia in developmental disorders and disease. Development 2006, 133, 4131-4143. [CrossRef] [PubMed]

37. Basten, S.; Giles, R. Functional aspects of primary cilia in signaling, cell cycle and tumorigenesis. Cilia 2013, 2, 6. [CrossRef] [PubMed]

38. Wong, S.; Reiter, J. The primary cilium at the crossroads of mammalian hedgehog signaling. Curr. Top. Dev. Biol. 2008, 85, 225-260. [PubMed]

39. Sasai, N.; Briscoe, J. Primary cilia and graded Sonic Hedgehog signaling. Wiley Interdiscip. Rev. Dev. Biol. 2012, 1, 753-772. [CrossRef] [PubMed]

40. Bangs, F.; Anderson, K. Primary Cilia and Mammalian Hedgehog Signaling. Cold Spring Harb. Perspect. Biol. 2017, 9, a028175. [CrossRef] [PubMed]

41. Tasouri, E.; Tucker, K. Primary cilia and organogenesis: Is Hedgehog the only sculptor? Cell Tissue Res. 2011, 345, 21-40. [CrossRef] [PubMed]

42. Ingham, P.; Nakano, Y.; Seger, C. Mechanisms and functions of Hedgehog signalling across the metazoa. Nat. Rev. Genet. 2011, 12, 393-406. [CrossRef] [PubMed]

43. Briscoe, J.; Thérond, P. The mechanisms of Hedgehog signalling and its roles in development and disease. Nat. Rev. Mol. Cell Biol. 2013, 14, 416-429. [CrossRef] [PubMed]

44. Lee, R.; Zhao, Z.; Ingham, P. Hedgehog signalling. Development 2016, 143, 367-372. [CrossRef] [PubMed]

45. Christ, A.; Christa, A.; Kur, E.; Lioubinski, O.; Bachmann, S.; Willnow, T.; Hammes, A. LRP2 is an auxiliary $\mathrm{SHH}$ receptor required to condition the forebrain ventral midline for inductive signals. Dev. Cell. 2012, 22, 268-278. [CrossRef] [PubMed]

46. Corbit, K.; Aanstad, P.; Singla, V.; Norman, A.; Stainier, D.; Reiter, J. Vertebrate Smoothened functions at the primary cilium. Nature 2005, 437, 1018-1021. [CrossRef] [PubMed]

47. Rohatgi, R.; Milenkovic, L.; Scott, M. Patched1 regulates hedgehog signaling at the primary cilium. Science 2007, 317, 372-376. [CrossRef] [PubMed]

48. Chen, M.; Wilson, C.; Li, Y.; Law, K.; Lu, C.; Gacayan, R.; Zhang, X.; Hui, C.; Chuang, P. Cilium-independent regulation of Gli protein function by Sufu in Hedgehog signaling is evolutionarily conserved. Genes Dev. 2009, 23, 1910-1928. [CrossRef] [PubMed]

49. Humke, E.; Dorn, K.; Milenkovic, L.; Scott, M.; Rohatgi, R. The output of Hedgehog signaling is controlled by the dynamic association between Suppressor of Fused and the Gli proteins. Genes Dev. 2010, 24, 670-682. [CrossRef] [PubMed]

50. Ruiz-Perez, V.; Blair, H.; Rodriguez-Andres, M.; Blanco, M.; Wilson, A.; Liu, Y.; Miles, C.; Peters, H.; Goodship, J. Evc is a positive mediator of Ihh-regulated bone growth that localises at the base of chondrocyte cilia. Development 2007, 134, 2903-2912. [CrossRef] [PubMed]

51. Valencia, M.; Lapunzina, P.; Lim, D.; Zannolli, R.; Bartholdi, D.; Wollnik, B.; Al-Ajlouni, O.; Eid, S.; Cox, H.; Buoni, S.; et al. Widening the mutation spectrum of EVC and EVC2: Ectopic expression of Weyer variants in NIH 373 fibroblasts disrupts Hedgehog signaling. Hum. Mutat. 2009, 30, 1667-1675. [CrossRef] [PubMed]

52. Blair, H.; Tompson, S.; Liu, Y.; Campbell, J.; MacArthur, K.; Ponting, C.; Ruiz-Perez, V.; Goodship, J. Evc2 is a positive modulator of Hedgehog signalling that interacts with Evc at the cilia membrane and is also found in the nucleus. BMC Biol. 2011, 9, 14. [CrossRef] [PubMed]

53. Dorn, K.; Hughes, C.; Rohatgi, R. A Smoothened-Evc2 complex transduces the Hedgehog signal at primary cilia. Dev. Cell 2012, 23, 823-835. [CrossRef] [PubMed] 
54. Yang, C.; Chen, W.; Chen, Y.; Jiang, J. Smoothened transduces Hedgehog signal by forming a complex with Evc/Evc2. Cell Res. 2012, 22, 1593-1604. [CrossRef] [PubMed]

55. Caparrós-Martín, J.; Valencia, M.; Reytor, E.; Pacheco, M.; Fernandez, M.; Perez-Aytes, A.; Gean, E.; Lapunzina, P.; Peters, H.; Goodship, J.; et al. The ciliary Evc/Evc2 complex interacts with Smo and controls Hedgehog pathway activity in chondrocytes by regulating Sufu/Gli3 dissociation and Gli3 trafficking in primary cilia. Hum. Mol. Genet. 2013, 22, 124-139. [CrossRef] [PubMed]

56. Ko, H.; Norman, R.; Tran, J.; Fuller, K.; Fukuda, M.; Eggenschwiler, J. Broad-minded links cell cycle-related kinase to cilia assembly and hedgehog signal transduction. Dev. Cell 2010, 18, 237-247. [CrossRef] [PubMed]

57. Keady, B.; Samtani, R.; Tobita, K.; Tsuchya, M.; San Agustin, J.; Follit, J.; Jonassen, J.; Subramanian, R.; Lo, C.; Pazour, G. IFT25 Links the Signal-Dependent Movement of Hedgehog Components to Intraflagellar Transport. Dev. Cell 2012, 22, 940-951. [CrossRef] [PubMed]

58. Eguether, T.; San Agustin, J.; Keady, B.; Jonassen, J.; Liang, Y.; Francis, R.; Tobita, K.; Johnson, C.; Abdelhamed, Z.; Lo, C.; et al. IFT27 links the BBSome to IFT for maintenance of the ciliary signaling compartment. Dev. Cell 2014, 31, 279-290. [CrossRef] [PubMed]

59. Yang, N.; Li, L.; Eguether, T.; Sundberg, J.; Pazour, G.; Chen, J. Intraflagellar transport 27 is essential for hedgehog signaling but dispensable for ciliogenesis during hair follicle morphogenesis. Development 2015, 142, 2194-2202. [CrossRef] [PubMed]

60. Wang, B.; Fallon, J.; Beachy, P. Hedgehog-regulated processing of Gli3 produces an anterior/posterior repressor gradient in the developing vertebrate limb. Cell 2000, 100, 423-434. [CrossRef]

61. Gerhardt, C.; Lier, J.; Burmühl, S.; Struchtrup, A.; Deutschmann, K.; Vetter, M.; Leu, T.; Reeg, S.; Grune, T.; Rüther, U. The transition zone protein Rpgrip1l regulates proteasomal activity at the primary cilium. J. Cell Biol. 2015, 210, 115-133. [CrossRef] [PubMed]

62. Gerhardt, C.; Wiegering, A.; Leu, T.; Rüther, U. Control of Hedgehog signalling by the cilia-regulated proteasome. J. Dev. Biol. 2016, 4, 27. [CrossRef]

63. Tuson, M.; He, M.; Anderson, K. Protein kinase A acts at the basal body of the primary cilium to prevent Gli2 activation and ventralization of the mouse neural tube. Development 2011, 138, 4921-4930. [CrossRef] [PubMed]

64. Wang, B.; Li, Y. Evidence for the direct involvement of $\beta \mathrm{TrCP}$ in Gli3 protein processing. Proc. Natl. Acad. Sci. USA 2006, 103, 33-38. [CrossRef] [PubMed]

65. Pan, Y.; Bai, C.; Joyner, A.; Wang, B. Sonic hedgehog signaling regulates Gli2 transcriptional activity by suppressing its processing and degradation. Mol. Cell Biol. 2006, 26, 3365-3377. [CrossRef] [PubMed]

66. He, M.; Subramanian, R.; Bangs, F.; Omelchenko, T.; Liem, K.J.; Kapoor, T.; Anderson, K. The kinesin-4 protein Kif7 regulates mammalian Hedgehog signalling by organizing the cilium tip compartment. Nat. Cell Biol. 2014, 16, 663-672. [CrossRef] [PubMed]

67. Cheung, H.; Zhang, X.; Ribeiro, A.; Mo, R.; Makino, S.; Puviindran, V.; Law, K.; Briscoe, J.; Hui, C. The kinesin protein Kif7 is a critical regulator of Gli transcription factors in mammalian hedgehog signaling. Sci. Signal. 2009, 2, ra29. [CrossRef] [PubMed]

68. Endoh-Yamagami, S.; Evangelista, M.; Wilson, D.; Wen, X.; Theunissen, J.; Phamluong, K.; Davis, M.; Scales, S.; Solloway, M.; de Sauvage, F.; et al. The mammalian Cos2 homolog Kif7 plays an essential role in modulating Hh signal transduction during development. Curr. Biol. 2009, 19, 1320-1326. [CrossRef] [PubMed]

69. Pedersen, L.; Akhmanova, A. Kif7 keeps cilia tips in shape. Nat. Cell Biol. 2014, 16, 623-625. [CrossRef] [PubMed]

70. Heydeck, W.; Zeng, H.; Liu, A. Planar cell polarity effector gene Fuzzy regulates cilia formation and Hedgehog signal transduction in mouse. Dev. Dyn. 2009, 238, 3035-3042. [CrossRef] [PubMed]

71. Washington Smoak, I.; Byrd, N.; Abu-Issa, R.; Goddeeris, M.; Anderson, R.; Morris, J.; Yamamura, K.; Klingensmith, J.; Meyers, E. Sonic hedgehog is required for cardiac outflow tract and neural crest cell development. Dev. Biol. 2005, 283, 357-372. [CrossRef] [PubMed]

72. Kerkela, R.; Kockeritz, L.; Macaulay, K.; Zhou, J.; Doble, B.; Beahm, C.; Greytak, S.; Woulfe, K.; Trivedi, C.; Woodgett, J.; et al. Deletion of GSK-3beta in mice leads to hypertrophic cardiomyopathy secondary to cardiomyoblast hyperproliferation. J. Clin. Investig. 2008, 118, 3609-3618. [CrossRef] [PubMed] 
73. Coles, G.; Ackerman, K. Kif7 is required for the patterning and differentiation of the diaphragm in a model of syndromic congenital diaphragmatic hernia. Proc. Natl. Acad. Sci. USA. 2013, 110, E1898-E1905. [CrossRef] [PubMed]

74. Johnson, D. Extra-toes: A new mutant gene causing multiple abnormalities in the mouse. J. Embryol. Exp. Morphol. 1967, 17, 543-581. [PubMed]

75. Patel, P.; Woodgett, J. Glycogen Synthase Kinase 3: A Kinase for All Pathways? Curr. Top. Dev. Biol. 2017, 123, 277-302. [PubMed]

76. Nakaya, M.; Biris, K.; Tsukiyama, T.; Jaime, S.; Rawls, J.; Yamaguchi, T. Wnt3a links left-right determination with segmentation and anteroposterior axis elongation. Development 2005, 132, 5425-5436. [CrossRef] [PubMed]

77. Bosada, F.; Devasthali, V.; Jones, K.; Stankunas, K. Wnt/ $\beta$-catenin signaling enables developmental transitions during valvulogenesis. Development 2016, 143, 1041-1054. [CrossRef] [PubMed]

78. Briggs, L.; Burns, T.; Lockhart, M.; Phelps, A.; Van den Hoff, M.; Wessels, A. Wnt/ $\beta$-catenin and sonic hedgehog pathways interact in the regulation of the development of the dorsal mesenchymal protrusion. Dev. Dyn. 2016, 245, 103-113. [CrossRef] [PubMed]

79. Niessen, K.; Karsan, A. Notch signaling in cardiac development. Circ. Res. 2008, 102, 1169-1181. [CrossRef] [PubMed]

80. Zhou, X.; Liu, J. Role of Notch signaling in the mammalian heart. Braz. J. Med. Biol. Res. 2014, 47, 1-10. [CrossRef] [PubMed]

81. Wurdak, H.; Ittner, L.; Lang, K.; Leveen, P.; Suter, U.; Fischer, J.; Karlsson, S.; Born, W.; Sommer, L. Inactivation of TGFbeta signaling in neural crest stem cells leads to multiple defects reminiscent of DiGeorge syndrome. Genes Dev. 2005, 19, 530-535. [CrossRef] [PubMed]

82. Choudhary, B.; Ito, Y.; Makita, T.; Sasaki, T.; Chai, Y.; Sucov, H. Cardiovascular malformations with normal smooth muscle differentiation in neural crest-specific type II TGF $\beta$ receptor (Tgfbr2) mutant mice. Dev. Biol. 2006, 289, 420-429. [CrossRef] [PubMed]

83. Chen, Q.; Chen, H.; Zheng, D.; Kuang, C.; Fang, H.; Zou, B.; Zhu, W.; Bu, G.; Jin, T.; Wang, Z.; et al. Smad7 is required for the development and function of the heart. J. Biol. Chem. 2009, 284, 292-300. [CrossRef] [PubMed]

84. Gray, R.; Abitua, P.; Wlodarczyk, B.; Szabo-Rogers, H.; Blanchard, O.; Lee, I.; Weiss, G.; Liu, K.; Marcotte, E.; Wallingford, J.; et al. The planar cell polarity effector Fuz is essential for targeted membrane trafficking, ciliogenesis and mouse embryonic development. Nat. Cell Biol. 2009, 11, 1225-1232. [CrossRef] [PubMed]

85. Dai, D.; Zhu, H.; Wlodarczyk, B.; Zhang, L.; Li, L.; Li, A.; Finnell, R.; Roop, D.; Chen, J. Fuz controls the morphogenesis and differentiation of hair follicles through the formation of primary cilia. J. Investig. Dermatol. 2011, 131, 302-310. [CrossRef] [PubMed]

86. Brooks, E.; Wallingford, J. Control of vertebrate intraflagellar transport by the planar cell polarity effector Fuz. J. Cell Biol. 2012, 198, 37-45. [CrossRef] [PubMed]

87. Zilber, Y.; Babayeva, S.; Seo, J.; Liu, J.; Mootin, S.; Torban, E. The PCP effector Fuzzy controls cilial assembly and signaling by recruiting Rab8 and Dishevelled to the primary cilium. Mol. Biol. Cell 2013, 24, 555-565. [CrossRef] [PubMed]

88. Du Toit, A. Organelle dynamics. KIF7 organizes cilia. Nat. Rev. Mol. Cell Biol. 2014, 15, 498-499. [CrossRef] [PubMed]

89. Digilio, M.; Marino, B.; Ammirati, A.; Borzaga, U.; Giannotti, A.; Dallapiccola, B. Cardiac malformations in patients with oral-facial-skeletal syndromes: Clinical similarities with heterotaxia. Am. J. Med. Genet. 1999, 84, 350-356. [CrossRef]

90. Sund, K.; Roelker, S.; Ramachandran, V.; Durbin, L.; Benson, D. Analysis of Ellis van Creveld syndrome gene products: Implications for cardiovascular development and disease. Hum. Mol. Genet. 2009, 18, 1813-1824. [CrossRef] [PubMed]

91. Calkoen, E.; Adriaanse, B.; Haak, M.; Bartelings, M.; Kolesnik, A.; Niszczota, C.; van Vugt, J.; Roest, A.; Blom, N.; Gittenberger-de Groot, A.; et al. How Normal is a 'Normal' Heart in Fetuses and Infants with Down Syndrome? Fetal Diagn. Ther. 2016, 39, 13-20. [CrossRef] [PubMed]

92. Goddeeris, M.; Schwartz, R.; Klingensmith, J.; Meyers, E. Independent requirements for Hedgehog signaling by both the anterior heart field and neural crest cells for outflow tract development. Development 2007, 134, 1593-1604. [CrossRef] [PubMed] 
93. Goddeeris, M.; Rho, S.; Petiet, A.; Davenport, C.; Johnson, G.; Meyers, E.; Klingensmith, J. Intracardiac septation requires hedgehog-dependent cellular contributions from outside the heart. Development 2008, 135, 1887-1895. [CrossRef] [PubMed]

94. Dyer, L.; Kirby, M. Sonic hedgehog maintains proliferation in secondary heart field progenitors and is required for normal arterial pole formation. Dev. Biol. 2009, 330, 305-317. [CrossRef] [PubMed]

95. Vincent, S.; Buckingham, M. How to make a heart: The origin and regulation of cardiac progenitor cells. Curr. Top. Dev. Biol. 2010, 90, 1-41. [PubMed]

96. Kelly, R. The second heart field. Curr. Top. Dev. Biol. 2012, 100, 33-65. [PubMed]

97. Francou, A.; Saint-Michel, E.; Mesbah, K.; Théveniau-Ruissy, M.; Rana, M.; Christoffels, V.; Kelly, R. Second heart field cardiac progenitor cells in the early mouse embryo. Biochim. Biophys. Acta 2013, 1833, 795-798. [CrossRef] [PubMed]

98. Hoffmann, A.; Peterson, M.; Friedland-Little, J.; Anderson, S.; Moskowitz, I. Sonic hedgehog is required in pulmonary endoderm for atrial septation. Development 2009, 136, 1761-1770. [CrossRef] [PubMed]

99. Xie, L.; Hoffmann, A.; Burnicka-Turek, O.; Friedland-Little, J.; Zhang, K.; Moskowitz, I. Tbx5-hedgehog molecular networks are essential in the second heart field for atrial septation. Dev. Cell 2012, 23, 280-291. [CrossRef] [PubMed]

100. Hoffmann, A.; Yang, X.; Burnicka-Turek, O.; Bosman, J.; Ren, X.; Steimle, J.; Vokes, S.; McMahon, A.; Kalinichenko, V.; Moskowitz, I. Foxf genes integrate tbx5 and hedgehog pathways in the second heart field for cardiac septation. PLoS Genet. 2014, 10, e1004604. [CrossRef] [PubMed]

101. Francou, A.; De Bono, C.; Kelly, R. Epithelial tension in the second heart field promotes mouse heart tube elongation. Nat. Commun. 2017, 8, 14770. [CrossRef] [PubMed]

102. Kathiriya, I.; Srivastava, D. Left-right asymmetry and cardiac looping: Implications for cardiac development and congenital heart disease. Am. J. Med. Genet. 2000, 97, 271-279. [CrossRef]

103. Komatsu, Y.; Mishina, Y. Establishment of left-right asymmetry in vertebrate development: The node in mouse embryos. Cell. Mol. Life Sci. 2013, 70, 4659-4666. [CrossRef] [PubMed]

104. Tanaka, Y.; Okada, Y.; Hirokawa, N. FGF-induced vesicular release of Sonic hedgehog and retinoic acid in leftward nodal flow is critical for left-right determination. Nature 2005, 435, 172-177. [CrossRef] [PubMed]

105. Tsiairis, C.; McMahon, A. An Hh-dependent pathway in lateral plate mesoderm enables the generation of left/right asymmetry. Curr. Biol. 2009, 19, 1912-1917. [CrossRef] [PubMed]

106. Schilling, T.; Concordet, J.; Ingham, P. Regulation of left-right asymmetries in the zebrafish by Shh and BMP4. Dev. Biol. 1999, 210, 277-287. [CrossRef] [PubMed]

107. Meyers, E.; Martin, G. Differences in left-right axis pathways in mouse and chick: Functions of FGF8 and SHH. Science 1999, 285, 403-406. [CrossRef] [PubMed]

108. Pagán-Westphal, S.; Tabin, C. The transfer of left-right positional information during chick embryogenesis. Cell 1998, 93, 25-35. [CrossRef]

109. Levin, M.; Johnson, R.; Stern, C.; Kuehn, M.; Tabin, C. A molecular pathway determining left-right asymmetry in chick embryogenesis. Cell 1995, 82, 803-814. [CrossRef]

110. Sutherland, M.; Ware, S. Disorders of left-right asymmetry: Heterotaxy and situs inversus. Am. J. Med. Genet. C. Semin. Med. Genet. 2009, 151C, 307-317. [CrossRef] [PubMed]

111. Ramsdell, A. Left-right asymmetry and congenital cardiac defects: Getting to the heart of the matter in vertebrate left-right axis determination. Dev. Biol. 2005, 288, 1-20. [CrossRef] [PubMed]

112. Zhou, L.; Liu, J.; Xiang, M.; Olson, P.; Guzzetta, A.; Zhang, K.; Moskowitz, I.; Xie, L. Gata4 potentiates second heart field proliferation and Hedgehog signaling for cardiac septation. Proc. Natl. Acad. Sci. USA 2017, 114, E1422-E1431. [CrossRef] [PubMed]

113. Roux, M.; Laforest, B.; Capecchi, M.; Bertrand, N.; Zaffran, S. Hoxb1 regulates proliferation and differentiation of second heart field progenitors in pharyngeal mesoderm and genetically interacts with Hoxa1 during cardiac outflow tract development. Dev. Biol. 2015, 406, 247-258. [CrossRef] [PubMed]

114. Vincent, S.; Mayeuf-Louchart, A.; Watanabe, Y.; Brzezinski, J.T.; Miyagawa-Tomita, S.; Kelly, R.; Buckingham, M. Prdm1 functions in the mesoderm of the second heart field, where it interacts genetically with Tbx1, during outflow tract morphogenesis in the mouse embryo. Hum. Mol. Genet. 2014, 23, 5087-5101. [CrossRef] [PubMed]

115. Kelly, R.; Brown, N.; Buckingham, M. The arterial pole of the mouse heart forms from Fgf10-expressing cells in pharyngeal mesoderm. Dev. Cell 2001, 1, 435-440. [CrossRef] 
116. Mjaatvedt, C.; Nakaoka, T.; Moreno-Rodriguez, R.; Norris, R.; Kern, M.; Eisenberg, C.; Turner, D.; Markwald, R. The outflow tract of the heart is recruited from a novel heart-forming field. Dev. Biol. 2001, 238, 97-109. [CrossRef] [PubMed]

117. Waldo, K.; Kumiski, D.; Wallis, K.; Stadt, H.; Hutson, M.; Platt, D.; Kirby, M. Conotruncal myocardium arises from a secondary heart field. Development 2001, 128, 3179-3188. [PubMed]

118. Mostefa-Kara, M.; Bonnet, D.; Belli, E.; Fadel, E.; Houyel, L. Anatomy of the ventricular septal defect in outflow tract defects: Similarities and differences. J. Thorac. Cardiovasc. Surg. 2015, 149, 682-688.e1. [CrossRef] [PubMed]

119. Gerhardt, C.; Lier, J.; Kuschel, S.; Rüther, U. The ciliary protein Ftm is required for ventricular wall and septal development. PLoS ONE 2013, 8, e57545. [CrossRef] [PubMed]

120. Bax, N.; Bleyl, S.; Gallini, R.; Wisse, L.; Hunter, J.; Van Oorschot, A.; Mahtab, E.; Lie-Venema, H.; Goumans, M.; Betsholtz, C.; et al. Cardiac malformations in Pdgfralpha mutant embryos are associated with increased expression of WT1 and Nkx2.5 in the second heart field. Dev. Dyn. 2010, 239, 2307-2317. [CrossRef] [PubMed]

121. Schatteman, G.; Motley, S.; Effmann, E.; Bowen-Pope, D. Platelet-derived growth factor receptor alpha subunit deleted Patch mouse exhibits severe cardiovascular dysmorphogenesis. Teratology 1995, 51, 351-366. [CrossRef] [PubMed]

122. Obican, S.; Finnell, R.; Mills, J.; Shaw, G.; Scialli, A. Folic acid in early pregnancy: A public health success story. FASEB J. 2010, 24, 4167-4174. [CrossRef] [PubMed]

123. Ruat, M.; Hoch, L.; Faure, H.; Rognan, D. Targeting of Smoothened for therapeutic gain. Trends Pharmacol. Sci. 2014, 35, 237-246. [CrossRef] [PubMed]

124. Chen, J.; Taipale, J.; Young, K.; Maiti, T.; Beachy, P. Small molecule modulation of Smoothened activity. Proc. Natl. Acad. Sci. USA 2002, 99, 14071-14076. [CrossRef] [PubMed]

125. Sinha, S.; Chen, J. Purmorphamine activates the Hedgehog pathway by targeting Smoothened. Nat. Chem. Biol. 2006, 2, 29-30. [CrossRef] [PubMed]

126. Nachtergaele, S.; Mydock, L.; Krishnan, K.; Rammohan, J.; Schlesinger, P.; Covey, D.; Rohatgi, R. Oxysterols are allosteric activators of the oncoprotein Smoothened. Nat. Chem. Biol. 2012, 8, 211-220. [CrossRef] [PubMed]

127. Gorojankina, T.; Hoch, L.; Faure, H.; Roudaut, H.; Traiffort, E.; Schoenfelder, A.; Girard, N.; Mann, A.; Manetti, F.; Solinas, A.; et al. Discovery, molecular and pharmacological characterization of GSA-10, a novel small-molecule positive modulator of Smoothened. Mol. Pharmacol. 2013, 83, 1020-1029. [CrossRef] [PubMed]

128. Watkins, D.; Berman, D.; Baylin, S. Hedgehog signaling: Progenitor phenotype in small-cell lung cancer. Cell Cycle 2003, 2, 196-198. [CrossRef] [PubMed]

129. Xie, J. Hedgehog signaling in prostate cancer. Future Oncol. 2005, 1, 331-338. [CrossRef] [PubMed]

130. Athar, M.; Tang, X.; Lee, J.; Kopelovich, L.; Kim, A. Hedgehog signalling in skin development and cancer. Exp. Dermatol. 2006, 15, 667-677. [CrossRef] [PubMed]

131. Daniel, V.; Peacock, C.; Watkins, D. Developmental signalling pathways in lung cancer. Respirology 2006, 11, 234-240. [CrossRef] [PubMed]

132. Douard, R.; Moutereau, S.; Pernet, P.; Chimingqi, M.; Allory, Y.; Manivet, P.; Conti, M.; Vaubourdolle, M.; Cugnenc, P.; Loric, S. Sonic Hedgehog-dependent proliferation in a series of patients with colorectal cancer. Surgery 2006, 139, 665-670. [CrossRef] [PubMed]

133. Evangelista, M.; Tian, H.; de Sauvage, F. The hedgehog signaling pathway in cancer. Clin. Cancer Res. 2006, 12, 5924-5928. [CrossRef] [PubMed]

134. Ma, X.; Sheng, T.; Zhang, Y.; Zhang, X.; He, J.; Huang, S.; Chen, K.; Sultz, J.; Adegboyega, P.; Zhang, H.; et al. Hedgehog signaling is activated in subsets of esophageal cancers. Int. J. Cancer 2006, 118, 139-148. [CrossRef] [PubMed]

135. Clement, V.; Sanchez, P.; de Tribolet, N.; Radovanovic, I.; Ruiz i Altaba, A. HEDGEHOG-GLI1 signaling regulates human glioma growth, cancer stem cell self-renewal, and tumorigenicity. Curr. Biol. 2007, 17, 165-172. [CrossRef] [PubMed]

136. Fukaya, M.; Isohata, N.; Ohta, H.; Aoyagi, K.; Ochiya, T.; Saeki, N.; Yanagihara, K.; Nakanishi, Y.; Taniguchi, H.; Sakamoto, H.; et al. Hedgehog signal activation in gastric pit cell and in diffuse-type gastric cancer. Gastroenterology 2006, 131, 14-29. [CrossRef] [PubMed] 
137. Barakat, M.; Humke, E.; Scott, M. Learning from Jekyll to control Hyde: Hedgehog signaling in development and cancer. Trends Mol. Med. 2010, 16, 337-348. [CrossRef] [PubMed]

138. Fish, E.; Parnell, S.; Sulik, K.; Baker, L.; Murdaugh, L.; Lamson, D.; Williams, K. Preaxial polydactyly following early gestational exposure to the smoothened agonist, SAG, in C57BL/6J mice. Birth Defects Res. 2017, 109, 49-54. [CrossRef] [PubMed]

139. Espinosa, L.; Inglés-Esteve, J.; Aguilera, C.; Bigas, A. Phosphorylation by glycogen synthase kinase- $3 \beta$ down-regulates Notch activity, a link for Notch and Wnt pathways. J. Biol. Chem. 2003, 278, 32227-32235. [CrossRef] [PubMed]

140. Caraci, F.; Gili, E.; Calafiore, M.; Failla, M.; La Rosa, C.; Crimi, N.; Sortino, M.; Nicoletti, F.; Copani, A.; Vancheri, C. TGF-beta1 targets the GSK-3beta/beta-catenin pathway via ERK activation in the transition of human lung fibroblasts into myofibroblasts. Pharmacol. Res. 2008, 57, 274-282. [CrossRef] [PubMed]

141. Strickland, S.; Smith, K.; Marotti, K. Hormonal induction of differentiation in teratocarcinoma stem cells: Generation of parietal endoderm by retinoic acid and dibutyryl cAMP. Cell 1980, 21, 347-355. [CrossRef]

142. Deol, G.; Cuthbert, T.; Gatie, M.; Spice, D.; Hilton, L.; Kelly, G. Wnt and Hedgehog Signaling Regulate the Differentiation of F9 Cells into Extraembryonic Endoderm. Front. Cell Dev. Biol. 2017, 5, 93. [CrossRef] [PubMed]

143. Vis, J.; Duffels, M.; Winter, M.; Weijerman, M.; Cobben, J.; Huisman, S.; Mulder, B. Down syndrome: A cardiovascular perspective. J. Intellect. Disabil. Res. 2009, 53, 419-425. [CrossRef] [PubMed]

144. Frid, C.; Drott, P.; Lundell, B.; Rasmussen, F.; Annerén, G. Mortality in Down's syndrome in relation to congenital malformations. J. Intellect. Disabil. Res. 1999, 43, 234-241. [CrossRef] [PubMed]

145. Freeman, S.; Bean, L.; Allen, E.; Tinker, S.; Locke, A.; Druschel, C.; Hobbs, C.; Romitti, P.; Royle, M.; Torfs, C.; et al. Ethnicity, sex, and the incidence of congenital heart defects: A report from the National Down Syndrome Project. Genet. Med. 2008, 10, 173-180. [CrossRef] [PubMed]

146. Laursen, H. Congenital heart disease in Down's syndrome. Br. Heart J. 1976, 38, 32-38. [CrossRef] [PubMed]

147. Currier, D.; Polk, R.; Reeves, R. A Sonic hedgehog (Shh) response deficit in trisomic cells may be a common denominator for multiple features of Down syndrome. Prog. Brain Res. 2012, 197, 223-236. [PubMed]

148. Blom, N.; Ottenkamp, J.; Wenink, A.; Gittenberger-de Groot, A. Deficiency of the vestibular spine in atrioventricular septal defects in human fetuses with down syndrome. Am. J. Cardiol. 2003, 91, 180-184. [CrossRef]

149. Snarr, B.; O’Neal, J.; Chintalapudi, M.; Wirrig, E.; Phelps, A.; Kubalak, S.; Wessels, A. Isl1 expression at the venous pole identifies a novel role for the second heart field in cardiac development. Circ. Res. 2007, 101, 971-974. [CrossRef] [PubMed]

150. Webb, S.; Anderson, R.; Lamers, W.; Brown, N. Mechanisms of deficient cardiac septation in the mouse with trisomy 16. Circ. Res. 1999, 84, 897-905. [CrossRef] [PubMed]

151. Roper, R.; Baxter, L.; Saran, N.; Klinedinst, D.; Beachy, P.; Reeves, R. Defective cerebellar response to mitogenic Hedgehog signaling in Down [corrected] syndrome mice. Proc. Natl. Acad. Sci. USA 2006, 103, 1452-1456. [CrossRef] [PubMed]

152. Das, I.; Park, J.; Shin, J.; Jeon, S.; Lorenzi, H.; Linden, D.; Worley, P.; Reeves, R. Hedgehog agonist therapy corrects structural and cognitive deficits in a Down syndrome mouse model. Sci. Transl. Med. 2013, 5, 201ra120. [CrossRef] [PubMed]

153. Gutierrez-Castellanos, N.; Winkelman, B.; Tolosa-Rodriguez, L.; Devenney, B.; Reeves, R.; De Zeeuw, C. Size does not always matter: Ts65Dn Down syndrome mice show cerebellum-dependent motor learning deficits that cannot be rescued by postnatal SAG treatment. J. Neurosci. 2013, 33, 15408-15413. [CrossRef] [PubMed]

(C) 2017 by the authors. Licensee MDPI, Basel, Switzerland. This article is an open access article distributed under the terms and conditions of the Creative Commons Attribution (CC BY) license (http:/ / creativecommons.org/licenses/by/4.0/). 